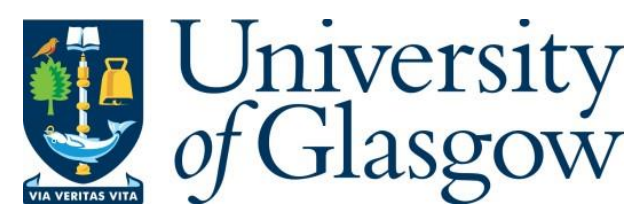

Littlejohn, A., Margaryan, A., Vojt, G. and Lukic, D. (2017) Learning from Incidents Questionnaire (LFIQ): the validation of an instrument designed to measure the quality of learning from incidents in organisations. Safety Science, 99(Part A), pp. 80-93.

There may be differences between this version and the published version. You are advised to consult the publisher's version if you wish to cite from it.

http://eprints.gla.ac.uk/185472/

Deposited on: 29 April 2019

Enlighten - Research publications by members of the University of Glasgow http://eprints.gla.ac.uk 


\title{
Learning from Incidents Questionnaire (LFIQ): The validation of an instrument designed to measure the quality of learning from incidents in organisations
}

\author{
Allison Littlejohn, Open University, UK \\ Anoush Margaryan, Gaby Vogt and Dane Lukic, Glasgow Caledonian University, UK
}

\begin{abstract}
Effective learning is essential for a safe workplace. Through learning from incidents (LFI), knowledge is applied and embedded within the work environment in ways that can prevent future incidents. In order to improve their LFI processes, such as incident reporting and analysis, or the dissemination of investigation outputs, organisations need an instrument that allows them to diagnose the quality and effectiveness of their LFI processes, making sure that LFI leads to positive safety outcomes. This paper outlines an instrument that measures the quality of LFI processes and practices: the Learning from Incident Questionnaire (LFIQ). The LFIQ identifies employees' perceptions and experiences of LFI processes and practices. This paper describes the validation of the LFIQ instrument via a pilot study conducted at two energy companies involving 781 participants. Through factor analysis the instrument was shown to have sufficient validity to become a useful tool for industry; by gaining insight into employees' perspectives on LFI, frontline managers and supervisors can have evidence on which to base improvements to the local work environment and prioritise areas for improvement.
\end{abstract}

\section{Introduction}

Effective learning from incidents (LFI) is critical for safe working. It allows knowledge to be applied and embedded in work environments in ways that can prevent future incidents (Cooke \& Rohleder, 2006). However, learning processes often are not implemented effectively, since the design of LFI initiatives is seldom based on empirical evidence from research on Workplace and Organisational Learning (Lukic et al., 2010).

In many organisations, the activities designed to enable employees to learn from incidents are based around the dissemination of the findings from incident investigations (see for example Phimister et al., 2003; Lundberg et al., 2009). However, dissemination of incident information does not always result in learning and action to change professional practice in the ways that are needed to prevent 
future incidents. In order to learn people have to move beyond receiving incident information to actively engaging with this information and, where necessary, changing practice (Lukic et al., 2010). To do this employees have to apply and make sense of incident information in ways that are meaningful to their job role; they have to reflect on the information and actively connect it to their professional practice (Lukic et al., 2013).

There are at least two main problems in moving individual employees towards actively engaging with incident information and, when necessary, changing practice (Lukic et al., 2013). First, many LFI activities focus on employees receiving and reading incident information, rather than engaging with incident knowledge. Second, during work there are few opportunities for employees to reflect and make sense of incident information in relation to their own job role. This problem is particularly acute with frontline employees. Front line managers and supervisors are not always able to engage front line employees with incident information in ways that maximise reflection and sense making. The research reported in this article is part of a larger study that aimed to address these problems. The need for a tool to measure LFI activity across each industrial site, and even across the sector, was heralded by the Energy Institute, a membership organization that wanted to measure employees' perceptions and experiences of learning from incidents within and across organizations. The study, Engaging with Learning From Incidents (LFI-Engage, http://www.gcu.ac.uk/academy/lflengage/), was funded by the Energy Institute to improve the effectiveness of LFI in organisations by supporting front line managers and supervisors in understanding the current status of LFI capability at their site, how this can be improved and how to more effectively engage with frontline employees on learning from incidents. The main output was a Toolkit designed to support front line managers and supervisors, especially with regards to encouraging sense-making and reflection within the LFI process. This paper reports the development and validation of a tool from the Toolkit, the LFI Questionnaire tool, which is designed to diagnose the quality of current LFI activities in an organisation with a view to understanding how these activities might impact on each individual's learning.

Research by Lähteenmäki et al. (2001) was the first to suggest that the initial step in improving LFI should be to examine existing LFI activities within each organisation. Arguably, this process calls for a valid and reliable instrument, which is sensitive to specific features of organisational learning (Easterby-Smith, 1998; Gherardi \& Nicolini, 2000). There are a number of methodological approaches that could be used to diagnose quality of LFI, including ethnographic (Buescher et al., 2009), 'sensemaking' (Snowden, 2002), socio-cultural (Sanne, 2008) and cognitive-psychology based approaches (Stanton \& Walker, 2011). The associated instruments are difficult for managers and supervisors to implement for various reasons - primarily because they are too specialised and technical to be used by non-researchers and are therefore out of scope for use by frontline staff.

LFI must be considered across the whole organization, or site, to capture all facets of the LFI process across different levels (Lukic et al., 2012a). The primary reason is because the cumulative effects of individual LFI activities across a site impact on the overall success - or failure - of LFI within an 
organisation. However, no instrument to measure LFI across an organization is currently available. This paper proposes an instrument, the Learning from Incident Questionnaire (LFIQ), to measure the quality of LFI processes and practice across an organization or site.

\section{Conceptual underpinnings}

A comprehensive review of the literature was conducted to investigate existing models to provide a theoretical and conceptual platform for the questionnaire. Chiva et al. (2006) summarise that diagnostic instruments measuring the effectiveness of organisational learning tend to focus on two conceptual areas: (1) learning activities and their sequence, and (2) specific factors facilitating effective learning. With regards to the former, instruments addressing learning activities and their sequencing typically measure discreet phases of the learning process, for example the work of Drupsteen, Groeneweg, and Zwetsloot (2013) who conceptualised LFI as a series of steps to understand loss of learning potential in the process. In contrast, facilitating learning is based on measuring well-established properties or components (i.e. factors) which aid in effective learning. These two features - the activities and the factors inherent to effective learning - are interrelated as the what and how of learning. That is, the activities required to achieve effective learning outcomes are triggered by the factors associated with effective learning. Both these notions have been incorporated into instruments designed to measure safety climates, such as the Nordic Safety Climate Questionnaire, where learning activities (the what) are a subscale of safety climate (Kines et al., 2011); specific factors that enable learning (the how) have also been considered subscales of safety climate instruments, for example, individual motivation (Nielsen, Hystad, \& Eid, 2016) and commitment to the workplace (Nielsen, Rasmussen, Glasscock, \& Spangenberg, 2008). There are also tools aimed specifically at measuring the quality of organisational learning that cover both conceptual features, such as the instrument for Organisational Climate for Learning from Errors at Work (OLE) (Putz et al., 2013) or the model proposed by Edmondson (1999) relating team psychological safety, learning behaviours and performance. However, these tools tend to focus on a single organisational factor (e.g., learning climate) rather than the quality of the overall LFI processes. The conceptual baseline for the LFIQ were two models, developed through earlier empirical research: the LFI Framework (Lukic et al., 2012a) and the LFI Process Model (Lukic et al., $2012 b$ ). The reason these models were selected is because they were the first within the literature in this field to explore learning activities across the various phases of LFI (Lukic et al., 2010).

\subsection{The LFI Process Model}

The LFI Process Model (Figure 1) is used to map LFI activities across a site to phases of the LFI lifecycle (Lukic et al., 2012b). The LFI Process Model was developed through analysis of LFI activity on different industrial sites. There are normally six phases of LFI: reporting incidents, 
investigating incidents, developing incident alerts, disseminating information, contextualising information and implementing actions.

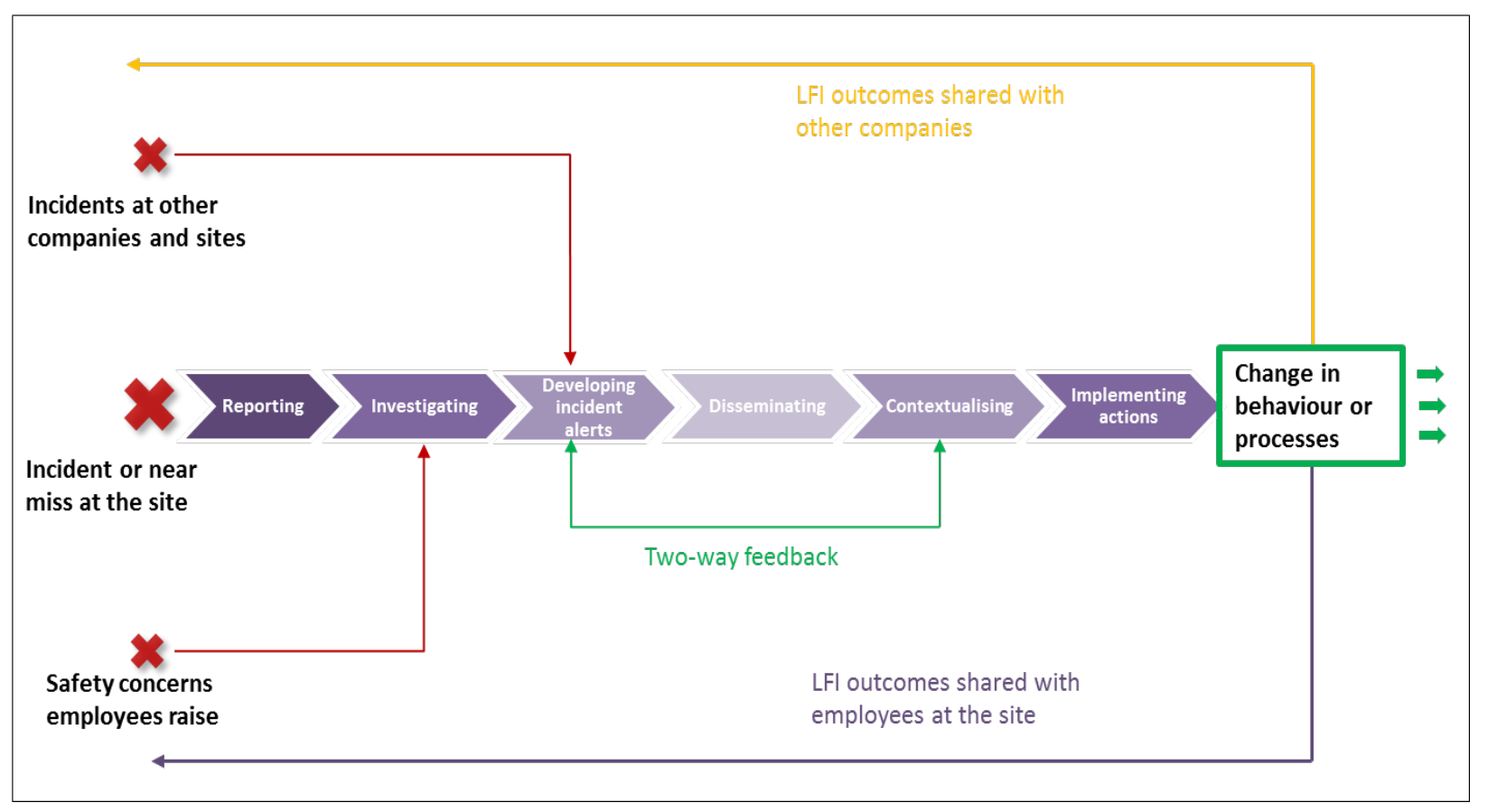

Figure 1. The LFI Process model

The LFI Process Model describes these phases as sequential. That is, (1) reporting an incident (including a near miss) is essential in raising awareness and allowing for preventive actions to be formulated. This leads to an (2) investigation of the incident(s) to determine both the immediate and underlying causes of the incident. Based on this investigation, recommendations for improving safety or changing practice are developed and shared across the relevant site in the form of an (3) incident alert. Incident alerts are tools to help employees understand how to prevent similar incidents from reoccurring. (4) Dissemination should be targeted towards relevant rather than all groups of workers, i.e., those employees who will benefit from each particular incident alert. The (5) contextualisation phase is important in learning as incident information has to be critically assessed and reflected upon within each employee's relevant workplace context. The final phase requires the (6) implementation of actions and changes by all relevant employees, thereby using the information with the aim of preventing similar incidents in the future.

This process forms a foundation to understand the effectiveness and inter-relationship of existing LFI activities on sites. 


\subsection{The LFI Framework}

Before 2012, Learning from Incidents was not underpinned by theories of organisational or adult learning (Lukic et al., 2012a). The LFI Framework (Figure 1) represents an early attempt to underpin LFI activity with these theories (ibid), taking into consideration critical components that influence organizational learning, such as how lessons are learned, the severity of the consequences of an incident and the people involved as well as team learning components, such as trust (Edmondson,1999). The Framework was selected as a baseline for the LFIQ because it integrates concepts from diverse yet related learning theories that: a) serve as analytical lenses to understand facets of LFI and b) provide prescriptive values when developing interventions in LFI. The framework is based on five key learning components identified through the literature as being important for effective LFI (for a detailed description of each component see Lukic et al., 2012a):

1. Learning context - learning might be organised and structured (e.g., courses or training) or could be informal (e.g., on-the-job learning). Informal learning is more difficult to perceive as 'learning' per se;

2. Learning participants - people in diverse roles or different areas of the organisation may prefer distinctive ways of learning;

3. Learning process - there are different reasons for learning that may require different processes. The learning process has to align with specific learning goals;

4. Type of incident - a large-scale and complex incident will require a different learning solution compared to a small-scale incident;

5. Type of knowledge - different sorts of activities are required to learn different types of knowledge. For example, theoretical and practical knowledge are learned in different ways. 


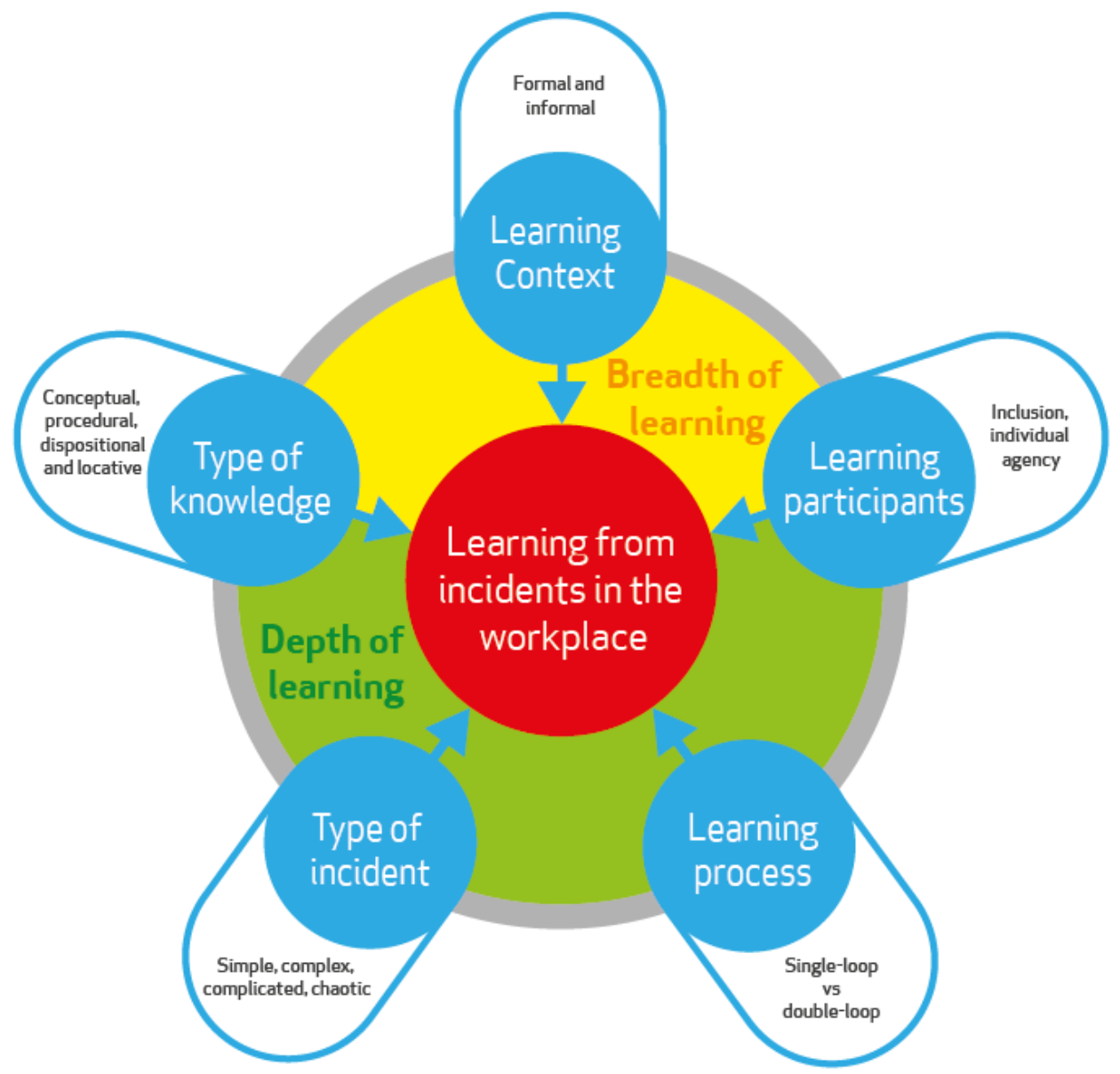

Figure 2. The LFI Framework (Lukic et al., 2012a)

These two perspectives, the temporal and sequential learning phases of the LFI Process Model and the underpinning learning components of the LFI Framework, function together in an effective LFI process.

\section{Design of LFIQ}

In line with the LFI Process Model and Framework used to inform the LFIQ, we developed two sets of related scales: the learning component scale (e.g., formality of learning) and the learning phase scale (e.g., reporting). Each learning component was broken down into specific dimensions, which were then coded with the relevant learning phases. The link between learning component dimensions 
and the related learning phases was achieved through formulating a latent question that would lead to the development of a specific statement. In other words, each phase of the LFI process contained multiple statements that would be rated to assess a learning component crucial during that phase. Appendix A details the operationalization of each of the five learning components, illustrating the latent questions and relevant learning phases from the LFI Process Model. For each learning component three or four latent questions were created, designed to capture the essence of a dimension of that particular learning component. For each latent question one to three learning phases was identified. A statement item was then developed for each of phase identified in a dimension of a component. Each statement was therefore associated with both a learning component and a learning phase. .

The questionnaire consisted of two parts. Part 1 related to the background of respondents ( 9 questions) while part 2 the statements outlined above which respondents rated using a 5 point Likert scale ranging from $1=$ strongly disagree to $5=$ strongly agree. Each question focuses on one learning component within a single phase of LFI.

There were five learning component scales:

1. Type of problem (6 items)

2. Learning participants (11 items)

3. Learning processes ( 8 items)

4. Type of knowledge (4 items), and

5. Formality of learning (5 items).

Matching these, six learning phase scales were developed:

1. Reporting (5 items)

2. Investigating (3 items)

3. Developing incident alerts (9 items)

4. Disseminating (8 items)

5. Contextualising (14 items), and

6. Implementing actions (6 items).

The 'developing incident alert' items were sensitive to respondents in that only those who indicated in Part 1 that they were involved in this particular process were asked to complete these items. This meant that the total questionnaire items ranged between 36 and 45 items depending on the 
respondent's designation. Table 1 outlines a number of item examples demonstrating how these map onto the learning component and the learning phase scales.

\section{Table 1. Examples of questionnaire items}

\begin{tabular}{|l|l|l|}
\hline Item & Learning component scale & Learning phase scale \\
\hline $\begin{array}{l}\text { Q23. Our company has a system in place } \\
\text { that allows all employees to easily report } \\
\text { incidents. }\end{array}$ & Participants of learning & Reporting \\
\hline $\begin{array}{l}\text { Q35. We consider if the incident } \\
\text { information we receive is relevant to our } \\
\text { own work. }\end{array}$ & Type of problem & Contextualising \\
\hline $\begin{array}{l}\text { Q44. The incident information we receive } \\
\text { helps us understand which procedures we } \\
\text { need to follow in order to prevent future } \\
\text { incidents. }\end{array}$ & Type of knowledge & Contextualising \\
\hline
\end{tabular}

\section{Validation of LFIQ}

We tested the validity and applicability of the LFIQ across two sites in two different, multinational, energy companies. Site 1 was a large upgrader site within a multinational company in the oil and gas sector in Canada, with around 1500 employees. Site 2 was a wind power plant within a UK energy company, with around 60 employees. We chose to include both sites in the utility testing to increase the applicability of the instrument to different companies. This noted, caution is advised as applicability does not necessarily infer generalisability. For example, the total sample size is limited, and therefore cannot be considered representative of diverse companies and sites.

\subsection{Content Validity}

Content validity was established through two mechanisms: expert interviews and a pilot study.

\subsubsection{Expert interviews}

To ensure that the instrument effectively captured the topic under investigation we interviewed 'experts', in other words, those who have an in-depth understanding of the topic of the instrument 
(LFI) through focus groups. The experts were front line managers, safety managers and contractor representatives. When designing the questsionnaire, we used principles of questionnaire design (Peterson, 2000; Oppenheim, 1996; Olsen, 2012). We also utilised feedback from six practitioners to sharpen the items prior to conducting the expert interviews in the form of focus groups. These focus groups were conducted on each of the two industrial sites. Sampling was facilitated by nominated gatekeepers who recruited a cross-section representing a stratified convenience sample. The Site 1 focus group comprised of 14 participants while the Site 2 focus group consisted of 7 interviewees. The focus groups were recorded, transcribed and coded using NVIVO. Thematic analysis was carried out on the focus groups transcripts. The reason thematic analysis was selected as a methodology, rather than open coding, was because the themes had already been established through the earlier literature review (Lukic et al, 2012). Thematic analysis was used to gather feedback from experts to understand if the items of the questionnaire reflected important themes within each category. This procedure was suggested by NassarMcMillan and Borders (2002, p. 6) who noted that although there are no clearly defined rules for the use of focus groups in measurement development, they aid in comparing groups' reactions to the same concepts and providing richer data for developing valid instruments. The coding was performed by one researcher and cross-coded independently by two further researchers. The coding was cross-checked and refined where inconsistencies arose to improve the overall reliability.

The emergent themes used for the analysis were defined by the earlier research on LFI phases and learning components. Qualitative analysis was used to determine whether sufficient content related validity evidence existed. Test content refers to the themes, wording, and format of the items, tasks, or questions on a test. Content validity was critical and the thematic analysis explored whether the items held the same meaning for people within and between groups and whether the items adequately operationalized the concepts they were developed to assess. If items were not found to adequately operationalize a concept then an attempt was made to determine whether this was due to unclear wording or insufficient shared conceptual understanding.

We used thematic

analysis to examine emergent themes within and between sites. Interviewees were asked to explain each LFIQ question in their own words. We also presented the outcomes of each question using the data gathered from their site and invited their views on the accuracy of the outcomes. 
Where appropriate, we revised items according to participants' feedback. For example, interviewees provided alternative wording suggestions for a number of items thought to be unclear. A detailed account of the methodology and results of the focus groups have been published elsewhere (Lukic et al., 2013). However, the validation of the LFIQ Tool within single-site testbeds in two organisations has not been published and is the focus of this paper. The pilot study is described below to provide a baseline for the instrument validation.

\subsubsection{Pilot study}

We conducted a pilot study in order to test the clarity of the LFIQ questions. The aim of the pilot study was to assess how well the wording of the LFIQ questions would be understood by the target user groups. We purposefully selected nine practitioners who worked in one of the two energy companies involved in the study. To enhance the representativeness of the sample we included people from various roles at different levels across the organisational hierarchy. We aimed for a cross-section of practitioners, i.e. we chose individuals from diverse professional backgrounds, in order to provide diverse points of views and enhance representativeness across the organisation. All nine respondents received an online version of the LFIQ and were asked to comment on the clarity and structure of questions. Six practitioners completed the questionnaires, and two of these also agreed to a follow-up interview regarding the clarity of the questions. Based on the feedback, selected questions were modified to improve the clarity of the questionnaire in the initial phases of the instrument development.

\subsection{Construct Validity}

To determine construct validity, we distributed the LFIQ across both sites through site-wide bulletins sent via email. The bulletins invited employees to participate in the study, and provided a summary of the study and a rationale for the LFIQ. We informed all potential respondents that participation was voluntary. The total number of responses from Site 1 was 740 (response rate of 50\%) and 41 from Site 2 (response rate of 67\%). Table 2 indicates the number of respondents by role. While questionnaires dealing with perceptions can be susceptible to social desirability, i.e., respondents answering in ways they view as desirable rather than accurate, the effects of this were minimised in two ways: question design (questions related to organisational states rather than individual qualities), and by conducting the study as self-administered and anonymous (Nederhof, 1985).

Table 2: Number of respondents by role 


\begin{tabular}{lllll}
\hline Type of role & Site 1 & \multicolumn{2}{c}{ Site 2 } \\
& $\%$ & $\mathrm{~N}$ & $\%$ & $\mathrm{~N}$ \\
\hline Senior manager & 1.2 & 9 & 7.3 & 3 \\
Middle manager & 4.5 & 33 & 14.6 & 6 \\
Immediate supervisor of front-line/shop-floor workers & 14.5 & 107 & 26.8 & 11 \\
Front-line/Shop-floor worker & 68.9 & 510 & 46.3 & 19 \\
Health, Safety, Security, Environment (HSSE) Professional & 8.0 & 59 & 0 & 0 \\
& 1.1 & 8 & 4.9 & 2 \\
Administration & 1.9 & 14 & 0 & 0 \\
Missing values & & 740 & & 41 \\
Total & & & & \\
\hline
\end{tabular}

\section{Factor analysis}

A factor analysis was carried out to explore the underlying structure and statistical components of the LFIQ. An exploratory factor analysis is recommended when the underlying structure of the dataset is not known, and when there are no preconceived hypothesis regarding the number and nature of factors. A principle component analysis, in contrast, is of a more confirmatory nature. That is, this method seeks to confirm if the number of factors identified conform to the researchers' expectations based on previous results. An initial assessment of the data was carried out to determine the suitability of the data for factor analysis, i.e. whether the assumptions required for factor analysis have been met, and to determine sampling adequacy.

\section{Suitability and Sampling adequacy of data}

We initially assessed the suitability and sampling adequacy of the data via three methods: item-torespondent ratio, Kaiser-Meyer-Olkin measure of sampling adequacy and Bartlett's test of sphericity. The number of respondents from Site $1(\mathrm{~N}=740)$ was above the suggested 1:10 item-to-respondent ratio, making the scales suitable for factor analysis. The Kaiser-Meyer-Olkin measure of sampling adequacy of the Validation data ranged from .70 to .90 for all scales, which is above the minimum recommended value of .60. The Bartlett's test of sphericity for all scales was significant with $p<.001$, meeting the minimum requirement of $p<.05$. These tests indicated that the data at Site 1 were suitable for principal component analysis. Due to the small size of the sample from Site $2(\mathrm{~N}=41)$ factor analysis was not performed on the Site 2 dataset. Although the response rate from site 2 was 
relatively high (67\%), the number of responses is not sufficient to ensure that factor analysis results are meaningful.

\section{Principle Component Analysis}

Principal component analysis (PCA) was used both on a global and on a local scale for Site 1 . The global analysis reveals the importance of one prominent factor that could measure the global quality of LFI at the site. The relatively low number of observations with respect to the number of variables may produce inaccuracies in the estimation of the global correlation structure, though locally, factor analysis was also used on each scale separately, as they offered clear factor structure. We used varimax rotation despite the majority of scales being mono-factorial. This is in line with Gorsuch (1983) who recommends to use varimax rotation (for orthogonal rotation) if the 'simple structure is clear' in the data (p.205). In cases where the analysis resulted in factors with less than 3 variables loading more than 0.5, PCA was repeated limiting the number of factors (Barbaranelli, 2006).

\section{Global PCA}

A global PCA was used to identify which of the LFI variables correlate into single components. This test was carried out using the available data on the 'Developing incident alerts' scale. We ran the analysis on the complete questionnaire (125 questions) and, respectively, on the sub-questionnaire obtained after the removal of the Developing incident alerts scale (653 complete questionnaires with 36 questions).

Shapiro-Wilk normality tests on each question indicated non-normality in the distribution of observations. This is confirmed by a negative skew in each answer and the fact that answer " 4 " exceeds $50 \%$ in 26 out of the 45 questions. The conclusion of both diagonalisations are similar: one direction summarises a major proportion of the variance $(35.59 \%$ and $35.21 \%$, respectively for each diagonal). The remainder of the eigendirections accounts separately for very little (a maximum of $6.5 \%$, decreasing rapidly). The loadings for the one-factor factor analysis (in the first analysis) are illustrated below in Table 3 .

\section{Table 3: Loadings for the one-factor factor analysis}

\begin{tabular}{|l|l|l|}
\hline \multicolumn{2}{|l|}{ LFIQ question } & $\begin{array}{l}\text { One } \\
\text { Factor } \\
\text { Loading }\end{array}$ \\
\hline Q56 & Our company listens to employees' ideas and suggestions for improving safety. & 0.785 \\
\hline Q54 & $\begin{array}{l}\text { Employees are informed about the outcomes of implementation of incident } \\
\text { prevention recommendations/actions. }\end{array}$ & 0.767 \\
\hline
\end{tabular}




\begin{tabular}{|c|c|c|}
\hline Q39 & $\begin{array}{l}\text { The employees at this site can offer their recommendations for preventing future } \\
\text { incidents. }\end{array}$ & 0.749 \\
\hline Q52 & At our work-site, we learn from near misses and incidents. & 0.740 \\
\hline Q46 & $\begin{array}{l}\text { The incident information we receive helps us understand which procedures we } \\
\text { need to follow in order to prevent future incidents. }\end{array}$ & 0.734 \\
\hline Q45 & $\begin{array}{l}\text { We receive information about incidents that allows us to understand what really } \\
\text { happened and how we can learn from it. }\end{array}$ & 0.709 \\
\hline Q48 & $\begin{array}{l}\text { Incident information we receive suggests useful safety attitudes and values that can } \\
\text { help us prevent future incidents. }\end{array}$ & 0.707 \\
\hline Q51 & We make a clear plan of action at the end of safety meetings. & 0.695 \\
\hline Q50 & $\begin{array}{l}\text { At this work-site, we consider if we need to change the way we conduct work } \\
\text { based on the incident information we receive. }\end{array}$ & 0.678 \\
\hline Q23 & $\begin{array}{l}\text { Incident investigations are conducted in such a way that allows employees to be } \\
\text { honest. }\end{array}$ & 0.677 \\
\hline Q24 & $\begin{array}{l}\text { We identify all the root causes of an incident before implementing further } \\
\text { improvements. }\end{array}$ & 0.673 \\
\hline Q53 & $\begin{array}{l}\text { We discuss whether safety recommendations from previous incidents are } \\
\text { appropriate for our work before implementing them at our work-site. }\end{array}$ & 0.671 \\
\hline Q44 & We always receive responses to feedback we give on incident information. & 0.670 \\
\hline Q31 & $\begin{array}{l}\text { Employees at this site make sure that important information about incidents is } \\
\text { shared with other employees who might benefit from it. }\end{array}$ & 0.670 \\
\hline Q38 & $\begin{array}{l}\text { At our work-site, we receive all the relevant incident information discussed at } \\
\text { safety meetings. }\end{array}$ & 0.668 \\
\hline Q33 & $\begin{array}{l}\text { At this work-site, we discuss incidents and what to do to prevent them with our } \\
\text { colleagues outside safety meetings and safety-specific communications. }\end{array}$ & 0.668 \\
\hline Q40 & At our work-site, we often give feedback to the authors of incident information. & 0.663 \\
\hline Q49 & $\begin{array}{l}\text { There is a system in place for informal contribution of ideas and suggestions } \\
\text { regarding safety and past incidents. }\end{array}$ & 0.655 \\
\hline Q15 & $\begin{array}{l}\text { When preparing incident information/lessons learned, we tell employees where to } \\
\text { find more information about the incident. }\end{array}$ & 0.640 \\
\hline Q32 & $\begin{array}{l}\text { Information about incidents reaches all employees, even if they were away (off } \\
\text { shift or on leave) when the incident information was disseminated. }\end{array}$ & 0.639 \\
\hline Q28 & $\begin{array}{l}\text { Employees are routinely informed about the progress and outcomes of incident } \\
\text { investigations. }\end{array}$ & 0.637 \\
\hline Q22 & $\begin{array}{l}\text { Our company has a system in place that allows all employees to easily report } \\
\text { incidents. }\end{array}$ & 0.634 \\
\hline Q42 & $\begin{array}{l}\text { We recognise when a piece of information about safety from our private } \\
\text { discussions is important for the rest of the organisation. }\end{array}$ & 0.632 \\
\hline Q43 & $\begin{array}{l}\text { We inform the safety department about good ideas related to safety that arise from } \\
\text { our informal discussions. }\end{array}$ & 0.620 \\
\hline Q25 & $\begin{array}{l}\text { Incident investigations are conducted by a professional team who understand the } \\
\text { nature of incidents. }\end{array}$ & 0.620 \\
\hline Q18 & At our site we report both incidents and near misses. & 0.606 \\
\hline Q47 & $\begin{array}{l}\text { We know where to find relevant information regarding incidents so that we can } \\
\text { prevent future similar incidents. }\end{array}$ & 0.602 \\
\hline Q36 & We actively discuss incident information with our colleagues. & 0.599 \\
\hline Q16 & $\begin{array}{l}\text { When we disseminate incident information/lessons learned, we outline the } \\
\text { attitudes and values that could help prevent another incident. }\end{array}$ & 0.585 \\
\hline Q27 & At our work-site, we receive incident information that is relevant to our work. & 0.583 \\
\hline
\end{tabular}




\begin{tabular}{|c|c|c|}
\hline Q29 & $\begin{array}{l}\text { Employees who do not regularly use computers at our work-site receive the same } \\
\text { information about incidents as other employees. }\end{array}$ & 0.582 \\
\hline Q41 & We can comment on incident information we receive if we disagree with it. & 0.577 \\
\hline Q20 & The management at our site consistently encourages reporting of incidents. & 0.560 \\
\hline Q13 & $\begin{array}{l}\text { When preparing incident information/lessons learned, we clearly point out why an } \\
\text { incident has occurred. }\end{array}$ & 0.547 \\
\hline Q17 & We can report incidents without fear of repercussions. & 0.520 \\
\hline Q14 & $\begin{array}{l}\text { When developing incident information/lessons learned, we clearly point out which } \\
\text { procedures need to be followed to avoid future incidents. }\end{array}$ & 0.490 \\
\hline Q26 & $\begin{array}{l}\text { At our work-site, we modify the way we learn from incidents depending on the } \\
\text { nature of the incident. }\end{array}$ & 0.472 \\
\hline Q11 & $\begin{array}{l}\text { Clear recommendations and actions are suggested in the incident } \\
\text { information/lessons learned we disseminate across the site after an incident. }\end{array}$ & 0.471 \\
\hline Q30 & $\begin{array}{l}\text { All employees eventually get to hear about incident information that other } \\
\text { colleagues discussed informally. }\end{array}$ & 0.438 \\
\hline Q37 & We continually question incident information we receive. & 0.438 \\
\hline Q9 & $\begin{array}{l}\text { When developing incident information/lessons learned, we adapt the content to } \\
\text { suit different employees who will be receiving them. }\end{array}$ & 0.415 \\
\hline Q35 & We consider if the incident information we receive is relevant to our own work. & 0.414 \\
\hline Q10 & $\begin{array}{l}\text { We apply different learning approaches when learning form complex incidents } \\
\text { compared with the approaches we use for simple incidents. }\end{array}$ & 0.375 \\
\hline Q12 & $\begin{array}{l}\text { When preparing incident information/lessons learned, we decide whether the } \\
\text { incident is relevant to the whole site or to specific work groups. }\end{array}$ & 0.343 \\
\hline Q21 & Incidents at our site do not get reported due to fear of negative consequences. & 0.332 \\
\hline Q19 & $\begin{array}{l}\text { At our workplace incidents are sometimes reported informally to colleagues } \\
\text { without a formal record of the report. }\end{array}$ & 0.217 \\
\hline Q55 & $\begin{array}{l}\text { We follow the recommendations/actions in incident information without } \\
\text { discussing them first. }\end{array}$ & 0.185 \\
\hline Q34 & $\begin{array}{l}\text { We hear about incidents through informal discussions with our colleagues rather } \\
\text { than through formal safety information systems. }\end{array}$ & 0.152 \\
\hline
\end{tabular}

There is a slight increase in the loadings for the latter questions, which indicates that this direction intuitively measures the global quality of LFI at the site and the last phase plays a prominent role in the questionnaire. However, no single component plays a specific role in determining the global quality of the Learning From Incidents Questionnaire.

\section{Local PCA}

\section{Learning Phase scales}

A local factor analysis was conducted using only the data from Site 1. Four learning phase scales were identified as mono-factorial (Reporting, Investigation and Disseminating and Implementing actions) and two as bi-factorial (Developing incident alerts and Dissemination). Table 4 describes the factor loadings for the four mono-factorial scales and illustrates how each item performs within each 
scale/component. The factor loadings for three questions (Q19, Q34 and Q55) were below the acceptable level of 0.5 . The PCA results for the mono-factorial LFI scales indicated that the learning phase scales can be viewed as bounded constructs.

Table 4. Factor analysis of the mono-factorial learning phase scales

\begin{tabular}{|c|c|c|c|}
\hline Scale & \multicolumn{2}{|c|}{ Items } & \multirow{2}{*}{$\begin{array}{l}\text { Factor loading } \\
0.77\end{array}$} \\
\hline & Q17 & $\begin{array}{l}\text { At our workplace incidents are sometimes reported } \\
\text { informally to colleagues without a formal record of the } \\
\text { report. }\end{array}$ & \\
\hline & Q18 & At our site we report both incidents and near misses. & 0.77 \\
\hline & Q21 & $\begin{array}{l}\text { Incidents at our site do not get reported due to fear of } \\
\text { negative consequences. }\end{array}$ & 0.71 \\
\hline & Q22 & $\begin{array}{l}\text { Our company has a system in place that allows all } \\
\text { employees to easily report incidents. }\end{array}$ & 0.65 \\
\hline & Q20 & $\begin{array}{l}\text { The management at our site consistently encourages } \\
\text { reporting of incidents. }\end{array}$ & 0.63 \\
\hline & Q19 & $\begin{array}{l}\text { At our workplace incidents are sometimes reported } \\
\text { informally to colleagues without a formal record of the } \\
\text { report. }\end{array}$ & $0.37 *$ \\
\hline \multirow[t]{3}{*}{ Investigating } & Q24 & $\begin{array}{l}\text { We identify all the root causes of an incident before } \\
\text { implementing further improvements. }\end{array}$ & 0.85 \\
\hline & Q23 & $\begin{array}{l}\text { Incident investigations are conducted in such a way } \\
\text { that allows employees to be honest. }\end{array}$ & 0.84 \\
\hline & Q25 & $\begin{array}{l}\text { Incident investigations are conducted by a professional } \\
\text { team who understand the nature of incidents. }\end{array}$ & 0.84 \\
\hline \multirow[t]{8}{*}{ Disseminating } & Q31 & $\begin{array}{l}\text { Employees at this site make sure that important } \\
\text { information about incidents is shared with other } \\
\text { employees who might benefit from it. }\end{array}$ & 0.80 \\
\hline & Q28 & $\begin{array}{l}\text { Employees are routinely informed about the progress } \\
\text { and outcomes of incident investigations. }\end{array}$ & 0.78 \\
\hline & Q32 & $\begin{array}{l}\text { Information about incidents reaches all employees, } \\
\text { even if they were away (off shift or on leave) when the } \\
\text { incident information was disseminated. }\end{array}$ & 0.78 \\
\hline & Q27 & $\begin{array}{l}\text { At our work-site, we receive incident information that } \\
\text { is relevant to our work. }\end{array}$ & 0.71 \\
\hline & Q29 & $\begin{array}{l}\text { Employees who do not regularly use computers at our } \\
\text { work-site receive the same information about incidents } \\
\text { as other employees. }\end{array}$ & 0.71 \\
\hline & Q33 & $\begin{array}{l}\text { At this work-site, we discuss incidents and what to do } \\
\text { to prevent them with our colleagues outside safety } \\
\text { meetings and safety-specific communications. }\end{array}$ & 0.68 \\
\hline & Q30 & $\begin{array}{l}\text { All employees eventually get to hear about incident } \\
\text { information that other colleagues discussed informally. }\end{array}$ & 0.64 \\
\hline & Q26 & $\begin{array}{l}\text { At our work-site, we modify the way we learn from } \\
\text { incidents depending on the nature of the incident. }\end{array}$ & 0.56 \\
\hline
\end{tabular}




\begin{tabular}{|l|l|l|l|}
\hline & Q34 & $\begin{array}{l}\text { We hear about incidents through informal discussions } \\
\text { with our colleagues rather than through formal safety } \\
\text { information systems. }\end{array}$ & $0.38^{*}$ \\
\hline $\begin{array}{l}\text { Implementing } \\
\text { actions }\end{array}$ & Q51 & $\begin{array}{l}\text { We make a clear plan of action at the end of safety } \\
\text { meetings. }\end{array}$ & 0.81 \\
\cline { 2 - 4 } & Q53 & $\begin{array}{l}\text { We discuss whether safety recommendations from } \\
\text { previous incidents are appropriate for our work before } \\
\text { implementing them at our work-site. }\end{array}$ & 0.80 \\
\cline { 2 - 4 } & Q54 & $\begin{array}{l}\text { Employees are informed about the outcomes of } \\
\text { implementation of incident prevention } \\
\text { recommendations/actions. }\end{array}$ & 0.79 \\
\cline { 2 - 4 } & Q52 & $\begin{array}{l}\text { At our work-site, we learn from near misses and } \\
\text { incidents. }\end{array}$ & 0.78 \\
\cline { 2 - 4 } & Q56 & $\begin{array}{l}\text { Our company listens to employees' ideas and } \\
\text { suggestions for improving safety. }\end{array}$ & 0.74 \\
\cline { 2 - 4 } & Q55 & $\begin{array}{l}\text { We follow the recommendations/actions in incident } \\
\text { information without discussing them first. }\end{array}$ & $-0.19^{*}$ \\
\hline
\end{tabular}

The bi-factorial learning phase scales are outlined below. The results of the analysis for the Developing incident alerts and the contextualising scales are illustrated in Table 5.

Table 5. Factor analysis of the Developing incident alerts and contextualising scale

\begin{tabular}{|c|c|c|c|c|}
\hline \multirow[t]{2}{*}{ Scale } & \multicolumn{2}{|c|}{ Items } & \multicolumn{2}{|c|}{$\begin{array}{l}\text { Factor } \\
\text { loading }\end{array}$} \\
\hline & & & 1 & 2 \\
\hline \multirow{8}{*}{$\begin{array}{l}\text { Developing } \\
\text { Incident } \\
\text { Alerts } \\
\text { Scale }\end{array}$} & Q13 & $\begin{array}{l}\text { When preparing incident information/lessons learned, we } \\
\text { clearly point out why an incident has occurred. }\end{array}$ & 0.79 & \\
\hline & Q16 & $\begin{array}{l}\text { When we disseminate incident information/lessons } \\
\text { learned, we outline the attitudes and values that could } \\
\text { help prevent another incident. }\end{array}$ & 0.75 & \\
\hline & Q14 & $\begin{array}{l}\text { When developing incident information/lessons learned, } \\
\text { we clearly point out which procedures need to be } \\
\text { followed to avoid future incidents. }\end{array}$ & 0.73 & \\
\hline & Q11 & $\begin{array}{l}\text { Clear recommendations and actions are suggested in the } \\
\text { incident information/lessons learned we disseminate } \\
\text { across the site after an incident. }\end{array}$ & 0.67 & \\
\hline & Q15 & $\begin{array}{l}\text { When preparing incident information/lessons learned, we } \\
\text { tell employees where to find more information about the } \\
\text { incident. }\end{array}$ & 0.66 & \\
\hline & Q10 & $\begin{array}{l}\text { We apply different learning approaches when learning } \\
\text { form complex incidents compared with the approaches } \\
\text { we use for simple incidents. }\end{array}$ & & 0.86 \\
\hline & Q9 & $\begin{array}{l}\text { When developing incident information/lessons learned, } \\
\text { we adapt the content to suit different employees who will } \\
\text { be receiving them. }\end{array}$ & & 0.84 \\
\hline & Q12 & $\begin{array}{l}\text { When preparing incident information/lessons learned, we } \\
\text { decide whether the incident is relevant to the whole site }\end{array}$ & & 0.72 \\
\hline
\end{tabular}




\begin{tabular}{|c|c|c|c|c|}
\hline & & or to specific work groups. & & \\
\hline \multirow[t]{16}{*}{$\begin{array}{l}\text { Contextuali } \\
\text { sing } \\
\text { scale }\end{array}$} & Q45 & $\begin{array}{l}\text { We receive information about incidents that allows us to } \\
\text { understand what really happened and how we can learn } \\
\text { from it. }\end{array}$ & 0.75 & \\
\hline & Q44 & $\begin{array}{l}\text { We always receive responses to feedback we give on } \\
\text { incident information. }\end{array}$ & 0.75 & \\
\hline & Q49 & $\begin{array}{l}\text { There is a system in place for informal contribution of } \\
\text { ideas and suggestions regarding safety and past incidents. }\end{array}$ & 0.75 & \\
\hline & Q47 & $\begin{array}{l}\text { We know where to find relevant information regarding } \\
\text { incidents so that we can prevent future similar incidents. }\end{array}$ & 0.73 & \\
\hline & Q48 & $\begin{array}{l}\text { Incident information we receive suggests useful safety } \\
\text { attitudes and values that can help us prevent future } \\
\text { incidents. }\end{array}$ & 0.68 & \\
\hline & Q38 & $\begin{array}{l}\text { At our work-site, we receive all the relevant incident } \\
\text { information discussed at safety meetings. }\end{array}$ & 0.67 & \\
\hline & Q43 & $\begin{array}{l}\text { We inform the safety department about good ideas related } \\
\text { to safety that arise from our informal discussions. }\end{array}$ & 0.62 & \\
\hline & Q40 & $\begin{array}{l}\text { At our work-site, we often give feedback to the authors of } \\
\text { incident information. }\end{array}$ & 0.62 & \\
\hline & Q39 & $\begin{array}{l}\text { The employees at this site can offer their } \\
\text { recommendations for preventing future incidents. }\end{array}$ & 0.61 & \\
\hline & Q41 & $\begin{array}{l}\text { We can comment on incident information we receive if } \\
\text { we disagree with it. }\end{array}$ & 0.60 & \\
\hline & Q50 & $\begin{array}{l}\text { At this work-site, we consider if we need to change the } \\
\text { way we conduct work based on the incident information } \\
\text { we receive. }\end{array}$ & 0.58 & \\
\hline & Q46* & $\begin{array}{l}\text { The incident information we receive helps us understand } \\
\text { which procedures we need to follow in order to prevent } \\
\text { future incidents. }\end{array}$ & $0.47^{*}$ & $0.17^{*}$ \\
\hline & Q37 & We continually question incident information we receive. & & 0.71 \\
\hline & Q36 & $\begin{array}{l}\text { We actively discuss incident information with our } \\
\text { colleagues. }\end{array}$ & & 0.69 \\
\hline & Q35 & $\begin{array}{l}\text { We consider if the incident information we receive is } \\
\text { relevant to our own work. }\end{array}$ & & 0.66 \\
\hline & Q42 & $\begin{array}{l}\text { We recognise when a piece of information about safety } \\
\text { from our private discussions is important for the rest of } \\
\text { the organisation. }\end{array}$ & & 0.52 \\
\hline
\end{tabular}

Results for the Developing incident alerts scale demonstrate that all variables load significantly onto the two sub-factors and provide good validity of the construct. All but one item had factor loadings above the standard; Q46 had loading just under the required 0.5 and was noted for further analysis.

\section{Learning Component Scales}

A second factor analysis was carried out using the learning component scales. Results indicate that four scales were mono-factorial (Type of problem, Learning participants, Type of knowledge and 
Formality of learning) and one was bi-factorial (Learning process). Table 6 illustrates the factor loadings for the mono-factorial learning component.

Table 6. Factor analysis for the mono-factorial learning component scales

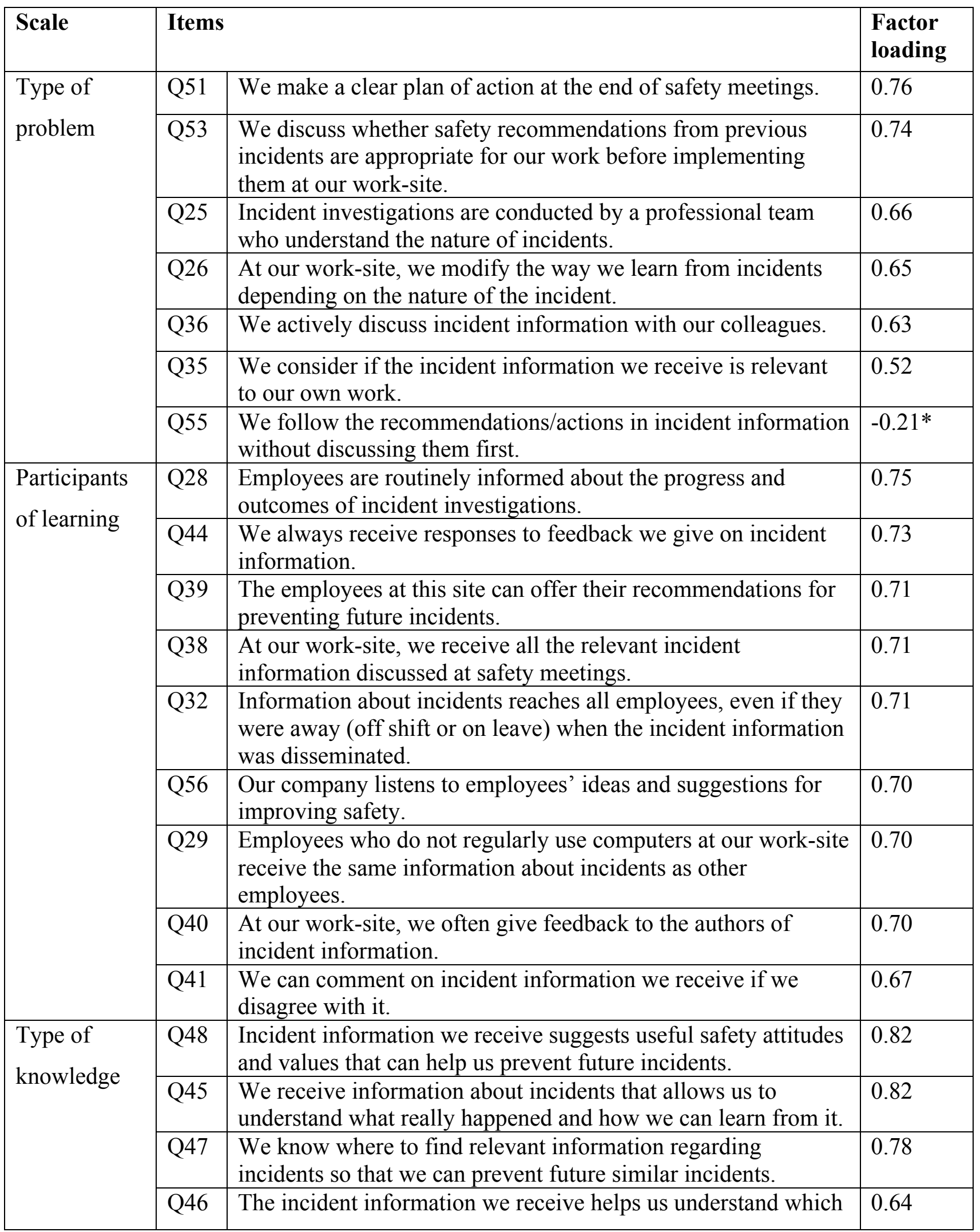




\begin{tabular}{|c|c|c|c|}
\hline & & $\begin{array}{l}\text { procedures we need to follow in order to prevent future } \\
\text { incidents. }\end{array}$ & \\
\hline \multirow[t]{6}{*}{$\begin{array}{l}\text { Formality of } \\
\text { learning }\end{array}$} & Q31 & $\begin{array}{l}\text { Employees at this site make sure that important information } \\
\text { about incidents is shared with other employees who might } \\
\text { benefit from it. }\end{array}$ & 0.79 \\
\hline & Q33 & $\begin{array}{l}\text { At this work-site, we discuss incidents and what to do to } \\
\text { prevent them with our colleagues outside safety meetings and } \\
\text { safety-specific communications. }\end{array}$ & 0.76 \\
\hline & Q32 & $\begin{array}{l}\text { Information about incidents reaches all employees, even if they } \\
\text { were away (off shift or on leave) when the incident information } \\
\text { was disseminated. }\end{array}$ & 0.75 \\
\hline & Q43 & $\begin{array}{l}\text { We inform the safety department about good ideas related to } \\
\text { safety that arise from our informal discussions. }\end{array}$ & 0.68 \\
\hline & Q42 & $\begin{array}{l}\text { We recognise when a piece of information about safety from } \\
\text { our private discussions is important for the rest of the } \\
\text { organisation. }\end{array}$ & 0.67 \\
\hline & Q34 & $\begin{array}{l}\text { We hear about incidents through informal discussions with our } \\
\text { colleagues rather than through formal safety information } \\
\text { systems. }\end{array}$ & $0.40^{*}$ \\
\hline
\end{tabular}

The results of the mono-factorial scales indicate that two questionnaire items do not load well onto the designed factors: Q55 and Q34. These items were marked for further analysis. Table 7 illustrates the factor analysis results for the Learning process scale.

Table 7. Factor analysis of the Learning process scale

\begin{tabular}{|c|c|c|c|}
\hline \multicolumn{2}{|l|}{ Items } & \multicolumn{2}{|c|}{$\begin{array}{l}\text { Factor } \\
\text { loading }\end{array}$} \\
\hline & & 1 & 2 \\
\hline Q23 & $\begin{array}{l}\text { Incident investigations are conducted in such a way that allows } \\
\text { employees to be honest. }\end{array}$ & 0.76 & \\
\hline RQ21 & $\begin{array}{l}\text { Incidents at our site do not get reported due to fear of negative } \\
\text { consequences. }\end{array}$ & 0.74 & \\
\hline Q24 & $\begin{array}{l}\text { We identify all the root causes of an incident before implementing } \\
\text { further improvements. }\end{array}$ & 0.66 & \\
\hline Q20 & $\begin{array}{l}\text { The management at our site consistently encourages reporting of } \\
\text { incidents. }\end{array}$ & 0.53 & \\
\hline Q37 & We continually question incident information we receive. & & 0.75 \\
\hline Q54 & $\begin{array}{l}\text { Employees are informed about the outcomes of implementation of } \\
\text { incident prevention recommendations/actions. }\end{array}$ & & 0.69 \\
\hline Q50 & $\begin{array}{l}\text { At this work-site, we consider if we need to change the way we conduct } \\
\text { work based on the incident information we receive. }\end{array}$ & & 0.61 \\
\hline Q52 & At our work-site, we learn from near misses and incidents. & & 0.60 \\
\hline
\end{tabular}

All items loaded above the minimum set in the procedure (0.5) indicating that all items can be retained for the Learning process scale. 


\section{Internal consistency}

The reliability of the instrument was tested using Cronbach's alpha. Cronbach's alpha was calculated for each learning component scale as well as for each learning phase scale. We further analysed all items which did not meet an acceptable level of internal consistency (i.e. $\alpha<.70$ ). There was good overall reliability of the LFIQ scales (Part 2): Site 1: $\alpha=0.95$; and Site 2: $\alpha=0.94$.

Table 8 illustrates reliability results for the learning phase scales at both sites, while table 9 indicates the Cronbach's alpha values for the learning component scales. Scales that did not meet the minimum criteria detailed in the analysis section are marked with an asterix $\left({ }^{*}\right)$.

Table 8. Reliability of the learning phase scales at both sites

\begin{tabular}{|c|c|c|c|c|c|c|c|}
\hline \multirow{2}{*}{$\begin{array}{l}\text { Learning phase } \\
\text { scale }\end{array}$} & \multirow{2}{*}{$\begin{array}{l}\text { Number } \\
\text { of items }\end{array}$} & \multicolumn{3}{|c|}{ Site 1} & \multicolumn{3}{|c|}{ Site 2} \\
\hline & & $\mathbf{n}$ & $\%$ & $\alpha$ & $\mathbf{n}$ & $\%$ & $\alpha$ \\
\hline Reporting & 6 & 705 & 95.3 & 0.73 & 39 & 95.1 & 0.70 \\
\hline Investigating & 3 & 720 & 97.3 & 0.80 & 40 & 97.6 & 0.72 \\
\hline $\begin{array}{l}\text { Developing } \\
\text { incident alerts }\end{array}$ & 8 & 145 & 19.6 & 0.80 & 16 & 39 & $0.55^{*}$ \\
\hline Disseminating & 9 & 708 & 95.7 & 0.85 & 40 & 97.6 & 0.71 \\
\hline Contextualising & 16 & 689 & 93.1 & 0.90 & 40 & 97.6 & 0.91 \\
\hline $\begin{array}{l}\text { Implementing } \\
\text { actions }\end{array}$ & 6 & 709 & 95.8 & 0.73 & 40 & 97.6 & 0.77 \\
\hline
\end{tabular}

The Cronbach's alpha scores were acceptable (above 0.7) for all scales, except for the 'Developing incident alerts' scale at Site 2. However, this scale represents a branch of the questionnaire that was answered only by participants who actively develop alerts on the sites. This means that the number of respondents for the scale at Site 2 was small $(n=16)$, so it was not possible to draw conclusions about the reliability of the scale at Site 2. Overall, the remaining learning phases' reliability results show good reliability at both Sites.

Table 9. Reliability of the learning component scales

\begin{tabular}{lllllllll}
\hline Learning phase scale & $\begin{array}{l}\text { Number } \\
\text { of items }\end{array}$ & Site 1 & & \multicolumn{4}{c}{ Site 2 } \\
\cline { 3 - 8 } & & n & $\%$ & $\alpha$ & n & $\%$ & $\alpha$
\end{tabular}




\begin{tabular}{llllllll}
\hline Type of problem & 7 & 702 & 94.9 & 0.71 & 40 & 97.6 & 0.71 \\
Learning process & 10 & 687 & 92.8 & 0.83 & 39 & 95.1 & 0.79 \\
Participants of learning & 11 & 686 & 92.7 & 0.88 & 39 & 95.1 & 0.84 \\
Type of knowledge & 4 & 708 & 95.7 & 0.73 & 40 & 97.6 & 0.83 \\
Formality of learning & 8 & 688 & 93.0 & 0.74 & 39 & 95.1 & $0.65^{*}$ \\
\hline
\end{tabular}

Reliability tests across the learning component scales illustrated that all five learning component scales were reliable at Site 1. At Site 2 one of the five learning component scales (Formality of learning) did not result in the required level of reliability. By removing one item (Q34) the Formality of learning scale was tested within a satisfactory level of reliability $(\alpha=0.72)$. Although this reliability result was only shown for 39 responses at Site 2, Q34 was marked for further investigation in the factor analysis.

Inter-item correlations, and correlations between LFI components at both sites demonstrated significant relationships. While this was the case within each site, this did not translate to correlations across the two sites. This may mean that LFIQ items tap into the same underlying concept within each site, and therefore may be considered too narrow. This would be supported by the finding that LFI was largely mono-factorial.

\subsection{Revisions to the LFIQ instrument}

The reliability studies and the principal component analyses indicated that the instrument is reliable and valid; though four items (Q19, Q34, Q46 and Q55) required modification. Arguably, the decisions on problematic questions should also include feedback from the potential end users of the questionnaire. We therefore combined the suggestions from the focus groups with the results of the quantitative analyses in order to triangulate the data. In summary, we considered four criteria during the revision process:-

1. The results of the reliability study

2. The results of the factor analysis

3. The feedback received from the focus group at Site 1

4. The feedback received from the focus group at site 2

Only when at least 2 of the 4 criteria are not satisfied was an item modified or removed. The integrated analysis resulted in three groups of items. 
The first group comprised items which gave satisfactory results in reliability and factor analysis studies. Participants from both focus groups stated that these questions were clear. Table 10 offers an example of these questions. These items were retained in their original form. Unshaded cells indicate that a criterion was satisfied and white cells indicate that the criterion was satisfied.

Table 10 Items that satisfied all criteria

\begin{tabular}{|c|c|c|c|}
\hline Item & $\begin{array}{l}\text { Factor } \\
\text { analysis }\end{array}$ & Site 1 Focus group & Site 2 Focus group \\
\hline $\begin{array}{l}\text { Q32. Information } \\
\text { about incidents } \\
\text { reaches all } \\
\text { employees, even } \\
\text { if they were away } \\
\text { (off shift or on } \\
\text { leave) when the } \\
\text { incident } \\
\text { information was } \\
\text { disseminated. }\end{array}$ & $\begin{array}{l}\text { Factor } \\
\text { loading } \\
\text { satisfactory }\end{array}$ & $\begin{array}{l}\text { Participants thought } \\
\text { that the question was } \\
\text { clear and that the } \\
\text { results accurately } \\
\text { represent the site. }\end{array}$ & $\begin{array}{l}\text { Participants thought } \\
\text { that the question was } \\
\text { clear. A couple of } \\
\text { participants were } \\
\text { surprised that there } \\
\text { were any negative } \\
\text { responses to this } \\
\text { question. }\end{array}$ \\
\hline $\begin{array}{l}\text { Q20. The } \\
\text { management at } \\
\text { our site } \\
\text { consistently } \\
\text { encourages } \\
\text { reporting of } \\
\text { incidents. }\end{array}$ & $\begin{array}{l}\text { Factor } \\
\text { loading } \\
\text { satisfactory }\end{array}$ & $\begin{array}{l}\text { Participants thought } \\
\text { that the question was } \\
\text { clear and that the } \\
\text { results accurately } \\
\text { represent the site. }\end{array}$ & $\begin{array}{l}\text { Participants thought } \\
\text { that the question was } \\
\text { clear and that the results } \\
\text { accurately represent the } \\
\text { site. }\end{array}$ \\
\hline
\end{tabular}

The second group of items indicated problems in only one out of the four criteria. These items were also retained in the same format since problems in only one source do not justify modifying an otherwise valid item. Table 11 shows examples of items from the second group.

Table 11. Items that did not satisfy one criterion

\begin{tabular}{|l|l|l|}
\hline Item & Site 1 Focus group & Site 2 Focus group \\
\hline
\end{tabular}




\begin{tabular}{|c|c|c|}
\hline $\begin{array}{l}\text { Q35. We consider } \\
\text { if the incident } \\
\text { information we } \\
\text { receive is } \\
\text { relevant to our } \\
\text { own work. }\end{array}$ & $\begin{array}{l}\text { Participants thought } \\
\text { that the question was } \\
\text { clear and that the } \\
\text { results accurately } \\
\text { represent the site. }\end{array}$ & $\begin{array}{l}\text { A participant suggested } \\
\text { using 'whether' instead } \\
\text { of 'if' to clarify the } \\
\text { question. Another } \\
\text { participant thought that } \\
\text { 'Consideration is } \\
\text { given...' would be a } \\
\text { better structure. }\end{array}$ \\
\hline $\begin{array}{l}\text { Q46. The incident } \\
\text { information we } \\
\text { receive helps us } \\
\text { understand which } \\
\text { procedures we } \\
\text { need to follow in } \\
\text { order to prevent }\end{array}$ & $\begin{array}{l}\text { Participants thought } \\
\text { that the question was } \\
\text { clear and that the } \\
\text { results accurately } \\
\text { represent the site. }\end{array}$ & $\begin{array}{l}\text { Participants thought } \\
\text { that the question was } \\
\text { clear and that the results } \\
\text { accurately represent the } \\
\text { site. }\end{array}$ \\
\hline
\end{tabular}

The third group of items were the ones where at least two of the criteria were not satisfied and the question needed further modifying or removing. Table 12 indicates examples of these items. 